\title{
Peer support for the primiparous mother with postpartum depression: a scoping review
}

\author{
Eka Septianingrum ${ }^{1 *}$, Cesa Septiana Pratiwi ${ }^{2}$, Fitria Siswi Utami ${ }^{3}$ \\ ${ }^{1}$ Student of Master Program, Faculty of Health Science, Universitas 'Aisyiyah Yogyakarta, Siliwangi Street, \\ Yogyakarta 55292, Indonesia \\ ${ }^{2,3}$ Lecturer of Master Program, Faculty of Health Science, Universitas 'Aisyiyah Yogyakarta, Siliwangi Street, \\ Yogyakarta 55292, Indonesia \\ ${ }^{1}$ Septianingrumeka53@gmail.com; ${ }^{2}$ Pratiwi.cesa@gmail.com; ${ }^{3}$ Fitriasiswi@unisayogya.ac.id \\ *Corresponding author
}

Submission date: 25 Maret 2021, Receipt date: 9 Mei 2021, Publication date: 1 November 2021

\begin{abstract}
Postpartum depression is a global problem throughout the world. Research studies have found that based on this background, the researchers would know peer support for primiparous mothers with postpartum depression. This scooping review method used the framework from Arksey and O'Malley focusing on the PICO framework. Result: it showed that peer support for primiparous mothers with postpartum depression was very limited. Conclusion: This support is expected to be able to realize the biological and psychological well-being of mothers in the face of postpartum depression and to adapt their changing roles and minimize the occurrence of postpartum depression.
\end{abstract}

Keywords: postpartum depression; primiparous mothers; peer support

\section{INTRODUCTION}

According to the World Health Organization, the postpartum period begins after delivery and lasts 6-8 weeks. The postpartum period is very important in this phase of the life of both mother and newborn. Most of maternal and neonatal deaths occurred in the first month after birth, nearly half of postnatal maternal deaths occurred within the first 24 hours and 66\% occurred during the first week. In 2013, 2.8-2.9 million newborns died in their first month of life and one million babies were born on the first day (World Health Organization, 2013).

For the time being made globally in maternal health, each year an estimated 289,000 die worldwide due to complications related to pregnancy, childbirth, or the postpartum period, up to $2 / 3$ of maternal deaths occur after delivery, maternal and newborn deaths occur globally. Ninety-nine percent of deaths occurred in low- and middle-income countries (Idaiani et al., 2012).

Postpartum depression is a global problem throughout the world. Postpartum depression affects tens or even hundreds of thousands per year in all countries. Research studies have found that postpartum depression rates in Asian countries can reach $65 \%$ or more among primiparous mothers. Depression is a serious mental illness that is not only a cause for concern, but there is an impact on the fetus or child (Brummelt et al., 2016). Unfortunately, it is believed that postpartum depression is much more than is expressed in these statistics. Some medical experts believe it could even be twice what is actually reported and diagnosed, if symptoms are not reported and the symptoms are not treated, the symptoms cannot be counted in global health statistics (Haran et al., 2014). 
While in Indonesia phsycological problems in depression postpartum mothers have not received special attention. The postpartum depression incidence rate in Indonesia was recorded at $22.4 \%$. The incidence of postpartum depression in Asia is quite high and varied, but in Indonesia, one of them and several studies in Indonesia, one of which was in 2017 at the KIA Sadewa Hospital Yogyakarta, the incidence of postpartum depression was $7.7 \%$ this indicates the need to get attention considering that there are still many incidents that occur(Sari et al., 2020).

Depression is a public health problem that is twice as common in women as in men. Postpartum depression is defined in this report as non-psychotic episodes, this depression according to standard-based diagnostic criteria at one year per birth. These research studies consistently show that there are several causes that can be a strong predictor of postpartum depression, which are prolonged depression or anxiety during pregnancy, stressful life, poor social support and history of prior depression (Lorenzo et al., 2014).

Non-psychotic depression is the most common complication of childbirth affecting $10 \%-15 \%$ of women, and represents a sizeable public health problem affecting women and their families (Downs et al, 2008). Untreated postpartum depression can have lasting effects which is disadvantageous. For the mother, depression can be chronic recurring, and ongoing depression can contribute to emotional, behavioral, cognitive and interpersonal problems. There are three types of affective postpartum diseases, postpartum blues, labor depression, and postpartum psychosis (Muraca et al., 2014).

Peer support is an approach to give and receive assistance based on key principles such as respect, mutual responsibility and mutual agreement for benefits. This peer support can understand the mother's situation such as empathy and sympathy for the mother in her emotional and psychological feelings (Dennis et al., 2009). This peer support involves mothers and peer volunteers. These peer volunteers who have a previous history of postpartum depression. This peer support is provided and cannot be separated from mental health care in certain cases (Mahlke et al., 2014).

The existence of peer support is needed for mothers because this peer support program provides strength and helps mothers to adapt to changing roles experienced in life. This peer support can improve the health, physical and psychological well-being of the mother in dealing with postpartum depression (Prevatt et al., 2018). Based on the above background, the researcher is interested in doing a scooping review to describe peer support for primiparous mothers with postpartum depression. This special purpose is (1) Knowing the form of peer support that will be given to primiparous mother with postpartum depression, (2) Knowing the acces given to primiparous mothers with postpartum depression.

\section{RESEARCH METHOD}

The Scooping review method used the Arksey and O'malley (2005) framework. The steps are as follows identify research questions that are generally broad in nature, identify studies that are relevant and as complete as possible, study selection criteria inclusion or exclusion is based on literature, map data on the sifting stages of making 
flowcharts, and sort keyword information and theme problems, compile, summarize and report results with descriptive and numerical data, and thematic analysis data (Arksey and O’Malley, 2005).

\section{Identification of problems}

The formulation of the research questions used the PEOS framework (Population, Exposure, Outcomes). One of which was to describe peer support for primiparous mothers with postpartum depression. This process is used to identify keywords in an effective literature search strategy. Based on the framework above, the research question is "How is peer support for postpartum mothers?

Tabel 1. Frame Work PEOS

\begin{tabular}{ccc}
\hline Population & Exposure & Outcomes \\
\hline Primiparaous & Peer support & Postpartum depressions \\
\hline
\end{tabular}

\section{Identification which is relevant}

The second step is to identify the relevant articles. In the selection of relevant articles there are 4 databases such as Wiley Journal online, Pubmed, Science Direct, EBSCO which includes the Clinical Queries Strategy feature to achieve this, adopting a strategy that involves searching research evidence through various sources from electronic data to search for existing articles, relevant organizations and conferences. The search strategy for electronic databases is developed from research inquiries and defines the key concepts relevant to the keywords used "Peer and support" OR "Peer support" OR "Peer social group" AND "First time mothers" OR "First new mum" OR "First new mothers" OR "Primiparous postpartum depression" OR "Postnatal depression" OR "Perintal depression" OR "PPD". In the selection of relevant articles, the researcher chose the inclusion and exclusion criteria that will be used as the source of this scoping review. The following are the inclusion criteria:

Table 2. Framework criteria of inclusion and exclusion

\begin{tabular}{|c|c|}
\hline Criteria Inclusion & Criteria Exclusion \\
\hline 1. Recent articles 2005-2019 & 1. Opinion articles \\
\hline 2. Published in English. & 2. letters and book reviews \\
\hline $\begin{array}{l}\text { 3. Articles discussing forms of peer } \\
\text { support for primiparous mothers with } \\
\text { postpartum depression }\end{array}$ & $\begin{array}{l}\text { 3. Article reports, and } \\
\text { 4. Articles discussing peer support } \\
\text { for mothers with postpartum }\end{array}$ \\
\hline $\begin{array}{l}\text { 4. Articles discussing access to peer } \\
\text { support in primiparous mothers with } \\
\text { postpartum depression. }\end{array}$ & depression but not primiparous. \\
\hline $\begin{array}{l}\text { 5. Research primary and review article, } \\
\text { and }\end{array}$ & \\
\hline $\begin{array}{l}\text { 6. mothers who experience postpartum } \\
\text { depression }\end{array}$ & \\
\hline
\end{tabular}

\section{Selection of articles}

In the search for 4 databases and references, we found 167 articles, then 17 duplicate/double articles, so that we got 150 articles. 150 articles were screened from title and screening related to peer support in PPD mothers. It was re-screened and 86 irrelevant articles were found, then there were 64 full text screening articles re-identified and 
executed, found 56 articles, after which the results of 8 articles were found which were included in the inclusion and exclusion categories.

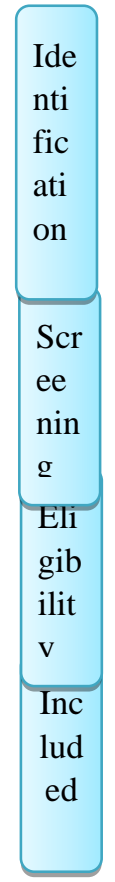

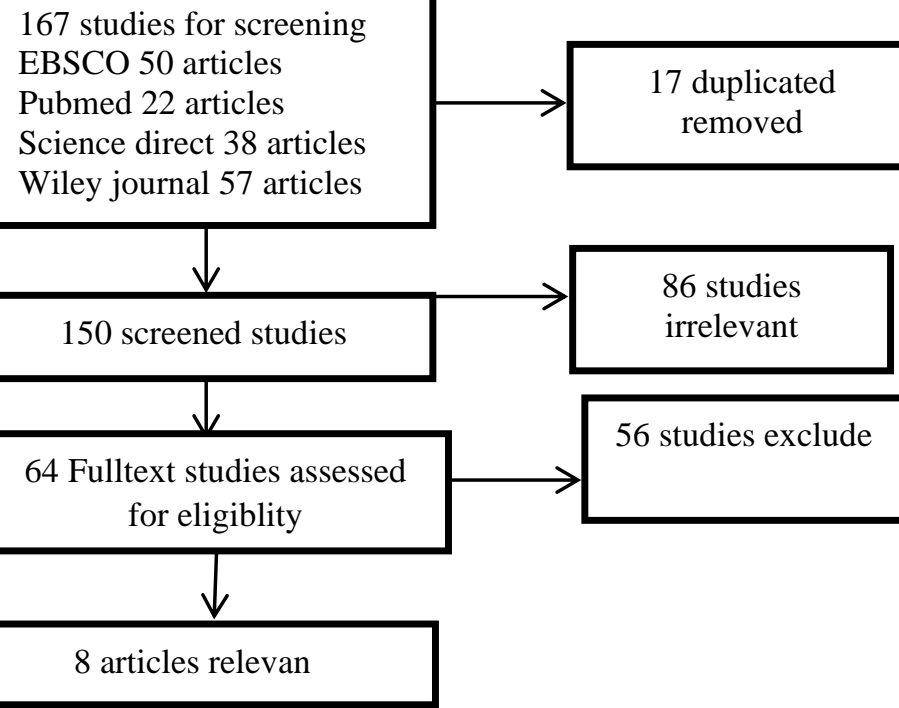

Figure 1.Prism flowchart

After selecting the study, to determine the quality of the articles that had been selected, a critical appraisal was performed to assess the quality of the articles to be used. The tool chosen to assess the quality of the articles in this scoping review was The JoannaBriggs Institute. In the critical appraisal stage, there were 8 articles that matched the topics and inclusion criteria that had been determined by the author. The 8 articles, there was the highest quality article number 3 with a score of 45 , and articles 4 and 7 have an average score of 41 , last and article number 1 have a low score of 41 . The study design used includes a quasi-experimental study, qualitative study, and randomized controlled trials. 


\section{Data Charting}

Table 3. Data charting

\begin{tabular}{|c|c|c|c|c|c|c|c|}
\hline NO & $\begin{array}{c}\text { Title/A } \\
\text { uthor/ } \\
\text { Grade/ } \\
\text { Year }\end{array}$ & $\begin{array}{c}\text { Research } \\
\text { setting }\end{array}$ & Purpose & $\begin{array}{c}\text { Research } \\
\text { design }\end{array}$ & $\begin{array}{c}\text { Data } \\
\text { Collection }\end{array}$ & $\begin{array}{c}\text { populati } \\
\text { on and } \\
\text { sample }\end{array}$ & Findings \\
\hline 1 & $\begin{array}{l}\text { (Letour } \\
\text { neau } \text { et } \\
\text { al., } \\
2015)\end{array}$ & Canada & $\begin{array}{l}\text { To effect } \\
\text { peer } \\
\text { support } \\
\text { and } \\
\text { social } \\
\text { support } \\
\text { using } \\
\text { telephon } \\
\text { e based } \\
\text { peer } \\
\text { support } \\
\text { with } \\
\text { mothers } \\
\text { postpartu } \\
\text { m } \\
\text { depressi } \\
\text { ons }\end{array}$ & $\begin{array}{l}\text { Quasi- } \\
\text { experiment } \\
\text { al, one } \\
\text { group pre- } \\
\text { test, } \\
\text { posttest }\end{array}$ & $\begin{array}{l}\text { Collecting } \\
\text { data } \\
\text { (Name and } \\
\text { telephone } \\
\text { for } \\
\text { interventio } \\
\text { n) }\end{array}$ & $\begin{array}{l}64 \\
\text { mothers } \\
\text { with } \\
\text { postpartu } \\
\text { m } \\
\text { depressi } \\
\text { on }\end{array}$ & $\begin{array}{l}\text { The research } \\
\text { results prove that } \\
\text { (TBPS) } \\
\text { Telephone based } \\
\text { peer support is } \\
\text { effective and } \\
\text { acceptable to } \\
\text { help and } \\
\text { overcome } \\
\text { maternal } \\
\text { depression }\end{array}$ \\
\hline 2 & $\begin{array}{l}\text { (Shorey } \\
\text { et al., } \\
\text { 2019) }\end{array}$ & Singapore & $\begin{array}{l}\text { Evaluate } \\
\mathrm{d} \text { the } \\
\text { postnatal } \\
\text { experien } \\
\text { ces of } \\
\text { Asian } \\
\text { mothers } \\
\text { at risk of } \\
\text { (PND) } \\
\text { postnatal } \\
\text { depressi } \\
\text { on and } \\
\text { perceptio } \\
\text { ns }\end{array}$ & $\begin{array}{l}\text { Randomize } \\
\text { d } \\
\text { Controlled } \\
\text { trials }\end{array}$ & $\begin{array}{l}\text { Semi- } \\
\text { structured } \\
\text { interview }\end{array}$ & $\begin{array}{l}20 \\
\text { mothers } \\
\text { with } \\
\text { postpartu } \\
\text { m } \\
\text { depressi } \\
\text { on }\end{array}$ & $\begin{array}{l}\text { Obtained } 2 \\
\text { themes } \\
\text { consisting of } 5 \\
\text { sub-themes, } \\
\text { namely: postnatal } \\
\text { experience and } \\
\text { evaluation(PIP) } \\
\text { Peer support } \\
\text { intervention } \\
\text { program. }\end{array}$ \\
\hline 3 & $\begin{array}{l}\text { (Letour } \\
\text { neau } \text { et } \\
\text { al., } \\
2016)\end{array}$ & Canada & $\begin{array}{l}\text { Investiga } \\
\text { ting } \\
\text { integrate } \\
\text { d } \\
\text { knowled } \\
\text { ge } \\
\text { transfer } \\
\text { in } \\
\text { mothers } \\
\text { and } \\
\text { approach } \\
\text { es in } \\
\text { telephon } \\
\text { e based } \\
\text { peer } \\
\text { support } \\
\text { (TBPS) } \\
\text { program }\end{array}$ & $\begin{array}{l}\text { Descriptive } \\
\text { qualitative } \\
\text { research }\end{array}$ & $\begin{array}{l}\text { Semi- } \\
\text { structured } \\
\text { interview }\end{array}$ & $\begin{array}{l}19 \\
\text { mothers } \\
\text { with } \\
\text { postpartu } \\
\text { m } \\
\text { depressi } \\
\text { on }\end{array}$ & $\begin{array}{l}\text { The findings } \\
\text { reveal a focus on } \\
\text { increasing the } \\
\text { clarity and } \\
\text { content of peer- } \\
\text { supported content }\end{array}$ \\
\hline
\end{tabular}




\begin{tabular}{|c|c|c|c|c|c|c|c|}
\hline & & & $\begin{array}{l}\mathrm{s} \text { in } \\
\text { postpartu } \\
\mathrm{m} \\
\text { depressi } \\
\text { on wome } \\
\mathrm{n}\end{array}$ & & & & \\
\hline 4 & $\begin{array}{l}\text { (Dennis } \\
\text { et al., } \\
\text { 2009) }\end{array}$ & Singapore & $\begin{array}{l}\text { Evaluatin } \\
\text { g the } \\
\text { effective } \\
\text { ness of } \\
\text { peer } \\
\text { support } \\
\text { program } \\
\text { s based } \\
\text { on } \\
\text { telephon } \\
\text { e based } \\
\text { peer } \\
\text { support } \\
\text { technolo } \\
\text { gy. }\end{array}$ & $\begin{array}{l}\text { Randomize } \\
\text { d controlled } \\
\text { trial. }\end{array}$ & $\begin{array}{l}\text { Structured } \\
\text { interview }\end{array}$ & $\begin{array}{l}701 \\
\text { mothers } \\
\text { with } \\
\text { postpartu } \\
\text { m } \\
\text { depressi } \\
\text { on }\end{array}$ & $\begin{array}{l}\text { telephone based } \\
\text { peer support } \\
\text { (TBPS) is } \\
\text { effective in } \\
\text { preventing } \\
\text { postpartum } \\
\text { depression in } \\
\text { high-risk mothers }\end{array}$ \\
\hline 5 & $\begin{array}{l}\text { (Shorey } \\
\text { et al., } \\
2018 \text { ) }\end{array}$ & Canada & $\begin{array}{l}\text { To } \\
\text { determin } \\
\text { e the } \\
\text { effective } \\
\text { ness of } \\
\text { peer } \\
\text { support } \\
\text { with } \\
\text { intervent } \\
\text { ion for } \\
\text { preventi } \\
\text { ng (PIP) } \\
\text { program } \\
\text { s }\end{array}$ & $\begin{array}{l}\text { Randomize } \\
\text { d controlled } \\
\text { trial }\end{array}$ & $\begin{array}{l}\text { Conducted } \\
\text { face-to- } \\
\text { face } \\
\text { interviews } \\
\text { with the } \\
\text { semi- } \\
\text { structure, } \\
\text { assessed } \\
\text { using the } \\
\text { Edinburgh } \\
\text { postnatal } \\
\text { depression } \\
\text { scale(EPD } \\
\text { S) with a } \\
\text { cut off } \\
\text { score of> } \\
10 .\end{array}$ & $\begin{array}{l}118 \\
\text { mothers } \\
\text { depressi } \\
\text { ons } \\
\text { postpartu } \\
\text { m }\end{array}$ & $\begin{array}{l}\text { Demonstrating } \\
\text { that peer support } \\
\text { is effective at } \\
\text { reducing a } \\
\text { mother's risk of } \\
\text { postpartum } \\
\text { depression, } \\
\text { receiving support } \\
\text { from others can } \\
\text { increase positive } \\
\text { parenting for } \\
\text { both mother and } \\
\text { baby. }\end{array}$ \\
\hline 6 & $\begin{array}{l}\text { (Dennis } \\
\text { et al., } \\
2010 \text { ) }\end{array}$ & Canada & $\begin{array}{l}\text { To } \\
\text { describe } \\
\text { the } \\
\text { mother's } \\
\text { perceptio } \\
\text { ns in } \\
\text { anticipati } \\
\text { on of } \\
\text { peer } \\
\text { support. }\end{array}$ & $\begin{array}{l}\text { Randomize } \\
\text { d controlled } \\
\text { trial }\end{array}$ & $\begin{array}{l}\text { There are } 2 \\
\text { groups, } \\
\text { namely the } \\
\text { control } \\
\text { and } \\
\text { interventio } \\
\mathrm{n} \text { test } \\
\text { groups. } \\
\text { Edinburgh } \\
\text { postnatal } \\
\text { depression } \\
\text { scale } \\
\text { (EPDS) } \\
\text { with a cut } \\
\text { off score } \\
\text { of }>10\end{array}$ & $\begin{array}{l}701 \\
\text { mothers } \\
\text { depressi } \\
\text { ons } \\
\text { postpartu } \\
\text { m }\end{array}$ & $\begin{array}{l}\text { The majority of } \\
\text { mothers have felt } \\
\text { or experienced } \\
\text { positively, and } \\
\text { provided good } \\
\text { feedback for the } \\
\text { mother's } \\
\text { telephone-based } \\
\text { peer support. }\end{array}$ \\
\hline
\end{tabular}




\begin{tabular}{|c|c|c|c|c|c|c|c|}
\hline 7 & $\begin{array}{l}\text { ( Dennis } \\
\text { et al., } \\
\text { 2014) }\end{array}$ & Canada & $\begin{array}{l}\text { To } \\
\text { evaluate } \\
\text { the } \\
\text { program, } \\
\text { this peer } \\
\text { support } \\
\text { intervent } \\
\text { ion is } \\
\text { based on } \\
\text { Telepho } \\
\text { ne based } \\
\text { peer } \\
\text { support } \\
\text { (TBPS). }\end{array}$ & $\begin{array}{l}\text { Randomize } \\
\text { d control } \\
\text { trial }\end{array}$ & $\begin{array}{l}\text { Mothers } \\
\text { were } \\
\text { recruited } \\
\text { with an } \\
\text { Edinburgh } \\
\text { postnatal } \\
\text { depression } \\
\text { scale(EPD } \\
\text { S) score } \\
\text { with a cut } \\
\text { off score } \\
\text { of>9. }\end{array}$ & $\begin{array}{l}701 \\
\text { mothers } \\
\text { depressi } \\
\text { ons } \\
\text { postpartu } \\
\text { m }\end{array}$ & $\begin{array}{l}\text { Overall, this } \\
\text { program is } \\
\text { feasible and has a } \\
\text { high level of } \\
\text { satisfaction for } \\
\text { mothers and } \\
\text { fellow mothers. }\end{array}$ \\
\hline 8 & $\begin{array}{l}\text { (Dennis } \\
\text { et al., } \\
\text { 2012) }\end{array}$ & Canada & $\begin{array}{l}\text { Evaluatin } \\
\mathrm{g} \\
\text { maternal } \\
\text { peer } \\
\text { support } \\
\text { based on } \\
\text { telephon } \\
\text { e-based } \\
\text { peer } \\
\text { support } \\
\text { (TBPS) } \\
\text { in } \\
\text { postpartu } \\
\text { m } \\
\text { depressi } \\
\text { on }\end{array}$ & $\begin{array}{l}\text { Randomize } \\
\text { d controlled } \\
\text { trial }\end{array}$ & $\begin{array}{l}\text { Volunteer } \\
\text { mothers } \\
\text { were } \\
\text { trained } \\
\text { and evaluat } \\
\text { ed for } 12 \\
\text { weeks. }\end{array}$ & $\begin{array}{l}205 \\
\text { mother } \\
\text { voluntee } \\
\text { rs were } \\
\text { recruited }\end{array}$ & $\begin{array}{l}\text { Overall, the } \\
\text { results of this } \\
\text { study are } \\
\text { effective and } \\
\text { positive from } \\
\text { continuous and } \\
\text { appropriate } \\
\text { peer support to } \\
\text { provide real help } \\
\text { to mothers who } \\
\text { experience } \\
\text { postnatal } \\
\text { depression. }\end{array}$ \\
\hline
\end{tabular}

\section{RESULT AND DISCUSSION}

Based on the 8 articles that were submitted, there were two syntheses in the form of grouped themes, which were peer support programs and peersupport content.

\section{Peer support program}

The first theme identified in all research related to peer support programs was divided into 7 main sub-themes, comprising of the use of technology by telephone, inperson meetings, peer support providers, peer recruitment processes, peer support training, evaluation of peer support programs, benefits of peer support programs and barriers to peer support programs, which are described in the article as follow:

\section{a. Use of telephone-based technology}

It was explained that Telephone-Based Peer Support Intervention (TBPS) was used because there were no peer support services for primiparous mothers who had previous postpartum depression, and no follow-up care for visits for primiparous mothers who were considered to be at high risk for health and social problems in the country (Letourneau et al., 2015). A telephone-based peer support intervention works with the Provincial government of Canada on community clinical services '811' to promote more accessible peer support for mothers with postpartum depression (Letourneau et al., 2016). 


\section{b. Meeting in person}

Mothers with postpartum depression undertook a 12-week peer support intervention with in-person and telephone-based meetings. Before being given the assignment to the mother, peer volunteers first assessed the suitability and interaction of the mother and the baby(Davidson et al., 2021). The volunteers conducted activities in the peer support class for 8 hours/day with practice sessions and questions and answers to the mother. Volunteers were trained to teach or assist some support to mothers such as informational support (information about postpartum depression), emotional support (sympathy, empathy and open discussion), social support (self-esteem and self-confidence) and childcare practices (Letourneau et al., 2011).

\section{c. Peer support providers}

Information support is provided by telephone by colleagues or volunteers who have been trained and have successfully recovered from previous postpartum depression (Letourneau et al., 2015). Mothers get volunteer or peer assistance for at least 1 month, at least colleagues or volunteers communicate with each other 1 time/week by communicating via: telephone calls, text messages, and WhatsApp (Shorey et al., 2019).

\section{d. Peer recruitment process}

Volunteers or colleagues are recruited through advertisements, posters, newspapers, television, internet, and radio. Colleagues or volunteers who are eligible for peer support have recovered from previous postpartum depression, and the results are seen from examinations with the Edinburgh Postnatal Depression Scale (EPDS) with a cut off score of $<6$. Colleagues or volunteers should: motivate and help mothers with PPD, volunteer age 19-45 years, speak fluent English or French and report a history of recovery from previous postpartum depression (Letourneau et al., 2015). Inclusion criteria from volunteers or colleagues: volunteers have a telephone and are willing to share a telephone number to communicate with mothers who experience postpartum depression (Shorey et al., 2019).

\section{e. Peer support training}

Colleagues attend an 8-hour training session to promote effective telephone-based peer support skills, such as: information support, emotional support and social support(Letourneau et al., 2015). Colleagues or volunteers undergo training to assist mothers who are at high risk of postpartum depression in building confidence and self-preparedness. Colleagues or volunteers receive training to teach how to provide telephone-based support effectively, and when to refer mothers to health professionals (Letourneau et al., 2016). Furthermore, volunteers are trained to provide text messages with a warm welcome via email or SMS (Short message service) (Shorey et al., 2019). 


\section{f. Evaluate peer support programs}

This peer support needs to be conducted. This program is effectively implemented By health professionals because it can help reduce the prevalence of postpartum depression. Moreover, peer support programs can not only introduce positive experiences and care for mothers, but can also reduce the adverse psychosocial impact of postpartum depression on individuals, families and the surrounding community (Shorey et al., 2019).

This opinion is supported by the statement of the volunteers who said that volunteers or colleagues are ready to participate to help mothers who experience postpartum depression. A total of two hundred and twenty-one mothers were reevaluated regarding the support provided by colleagues or volunteers saying this was a positive activity(McLeish et al,. 2021). As many as $80.5 \%$ of mothers were satisfied with this peer support program, and $85 \%$ of mothers agreed to recommend this peer support to other friends. Furthermore, $72 \%$ of mothers said that peer support program activities can meet the needs and wants of mothers (Dennis et al., 2014).

\section{g. The benefits of peer support}

Sharing experiences and knowledge from colleagues or volunteers can help overcome the negative stigma from those around them. Support is provided to mothers who experience postpartum depression such as: not judging the mother's beliefs, encouraging mother's recovery and providing relevant basic information related to postpartum depression to mothers (Letourneau et al., 2015). Volunteers and mothers establish good relationships such as positive social relationships, determined intentions, sincerity and respect, and can help reduce stress on mothers who experience postpartum depression (Shorey et al., 2019).

\section{h. Peer support program barriers}

Barriers in peer support programs such as: lack of knowledge or information on mothers regarding postpartum depression, differences in language between mothers and colleagues, and the presence of colleagues or volunteers who are unable to speak English to mothers (Letourneau et al., 2015).

\section{Peer support content}

The second theme identified throughout the research related to peer support content is divided into 3 main sub-themes: social support, emotional support, and informational support in articles as follows:

\section{a. Social support}

Social support is a psychosocial therapy that is accepted and effective for mothers to reduce postpartum depression. This is because social support can reduce the mother's sense of isolation (Letourneau et al., 2015). The role of social support, such as: volunteers or colleagues can provide coping strategies or appropriate self-appraisals to reduce maternal postpartum depression (Dennis et al., 2010). According to (Xie et al., 2009), it is explained that real social support such as how to care for newborns in postpartum depression mothers in Asia is very important. 


\section{b. Information support}

This information support is provided conveniently and provided over the telephone by colleagues or volunteers who have experience in a previous history of postpartum depression (Dennis et al., 2009). Support is provided with information such as: suggestions, advice, and open discussions in sharing experiences in understanding the problems felt by mothers (Xie et al., 2009).

\section{c. Emotional support}

The majority of mothers appreciate the advice provided by their peers. Mother feels that she has a friend to talk to about her problems, so that she feels that she is not alone. Mothers also feel more comfortable, more confident and reduce negative feelings that exist in themselves after receiving support from peers on an ongoing basis (Letourneau et al., 2016).

\section{CONCLUSION}

The occurrence of postpartum depression involves biological, psychological and social factors both before and after birth, for instance, suchas biological, psychological vulnerability, stressful situations and lack of support for mothers who experience postpartum depression. It was found that there were two syntheses, which were peer support programs and peer support content in primiparous mothers with postpartum depression.Peer support is quite helpful and very important for mothers. In essence, this support is expected to be able to realize maternal welfare both biologically and psychologically in the face of postpartum depression. This support will enable mothers to adapt to the changing roles they experience and minimize the occurrence of postpartum depression. Therefore, it is necessary to do further research related to the analysis of peer support needs in primiparous mothers with postpartum depression.

This study has provideda review regarding the outcome of peer support in primiparous mothers with postpartum depression. However, the researchers found a literature gaps in this study, among which there was no research on peer support programs in primiparous mothers with postpartum depression in developing countries. It is because mental health problems in developing countries are still considered taboo. Therefore, a study is needed, which is a need analysis of peer support for primiparous mothers who experience postpartum depression.

\section{REFERENCES}

Arksey, Hilary, and Lisa O'Malley. 2005. "Scoping Studies: Towards a Methodological Framework." International Journal of Social Research Methodology: Theory and Practice 8(1): 19-32.

Brummelte, Susanne, and Liisa A.M. Galea. 2016. "Postpartum Depression: Etiology, Treatment and Consequences for Maternal Care." Hormones and Behavior 77: 153-66.

Dennis, C. L. et al. 2009. "Effect of Peer Support on Prevention of Postnatal Depression among High Risk Women: Multisite Randomised Controlled Trial." BMJ (Online) 338(7689): 280-83. 
Dennis, Cindy-lee. 2012. "Peer Support for Postpartum Depression : Volunteers ' Perceptions , Recruitment Strategies and Training from a Randomized Controlled Trial." 28(2): 187-96.

Dennis, Cindy Lee. 2010. "Postpartum Depression Peer Support: Maternal Perceptions from a Randomized Controlled Trial." International Journal of Nursing Studies 47(5): 560-68.

Dennis, Cindy Lee. 2014. "The Process of Developing and Implementing a TelephoneBased Peer Support Program for Postpartum Depression: Evidence from Two Randomized Controlled Trials." Trials 15(1): 1-8.

Downs, Danielle Symons, Jennifer M. DiNallo, and Tiffany L. Kirner. 2008.

"Determinants of Pregnancy and Postpartum Depression: Prospective Influences of Depressive Symptoms, Body Image Satisfaction, and Exercise Behavior.” Annals of Behavioral Medicine 36(1): 54-63.

Gruß, Inga, Alison Firemark, and Autumn Davidson. 2021. "Motherhood, Substance Use and Peer Support: Benefits of an Integrated Group Program for Pregnant and Postpartum Women.” Journal of Substance Abuse Treatment 131(April).

Haran, Crishan, Mieke van Driel, Benjamin L. Mitchell, and Wendy E. Brodribb. 2014. "Clinical Guidelines for Postpartum Women and Infants in Primary Care-a Systematic Review.” BMC Pregnancy and Childbirth 14(1): 1-9.

Idaiani, Sri, and Bastaman Basuki. 2012. "Postpartum Depression in Indonesia Women: A National Study." Health Science Journal of Indonesia 3(1 Jun): 3-8.

Letourneau, Nicole et al. 2015. "Quasi-Experimental Evaluation of a Telephone-Based Peer Support Intervention for Maternal Depression." Journal of Advanced Nursing 71(7): 1587-99.

Letourneau, N et al ( 2016)." Development of a telephone-based peer support program for new mothers with postpartumdepression" 5: 48-57.

Lorenzo-Veigas, A. M., and M. Soto-González. 2014. "Risk Factors for Postpartum Depression." Fisioterapia 36(2): 87-94.

Mahlke, Candelaria I., Ute M. Krämer, Thomas Becker, and Thomas Bock. 2014. "Peer Support in Mental Health Services." Current Opinion in Psychiatry 27(4): 276-81.

McLeish, Jenny, Merryl Harvey, Maggie Redshaw, and Fiona Alderdice. 2021. “A Qualitative Study of First Time Mothers' Experiences of Postnatal Social Support from Health Professionals in England." Women and Birth 34(5): e451-60. https://doi.org/10.1016/j.wombi.2020.10.012.

Muraca, Giulia M., and K. S. Joseph. 2014. "The Association Between Maternal Age and Depression.” Journal of Obstetrics and Gynaecology Canada 36(9): 803-10.

Prevatt, Betty Shannon, Evan M. Lowder, and Sarah L. Desmarais. 2018. "Peer-Support 
Intervention for Postpartum Depression: Participant Satisfaction and Program Effectiveness." Midwifery 64: 38-47.

Sari, Retno Arienta. 2020. "Literature Review: Depresi Postpartum.” Jurnal Kesehatan 11(1): 167.

Shorey, Shefaly, Cornelia Chee, Yap-seng Chong, and Esperanza Debby Ng. "Evaluation of Technology-Based Peer Support Intervention Program for Preventing Postnatal Depression : Protocol for a Randomized Controlled Trial Corresponding Author :" 7.

Shorey, Shefaly, and Esperanza Debby Ng. 2019. "Evaluation of a Technology-Based Peer-Support Intervention Program for Preventing Postnatal Depression ( Part 2 ): Qualitative Study Corresponding Author :" 21(Part 2).

WHO. 2013. "Postnatal Care of the Mother and Newborn 2013." World Health Organization: 1-72. 